UDC 811.163.41'373

$811.163 .41^{\prime} 282.3$

https://doi.org/10.18485/bells.2018.10.14

\title{
Tanja Petrović"
}

Institute of Culture and Memory Studies

Research Centre, Slovenian Academy of Sciences and Arts

Ljubljana, Slovenia

\section{LINGUISTIC CREATIVITY: A VIEW FROM THE PERIPHERY OF THE SERBIAN LINGUISTIC SPACE}

\begin{abstract}
This article discusses linguistic strategies employed by the authors of the Facebook page Koe ima po grad ('What's up in the town'), an urban chronicle of Leskovac, and texts of the hip-hop band Southentik Crew from the town of Vlasotince. It offers a view on creativity as the strategic mixture of the local dialect with various, easily recognizable discourses and explores the ways in which it engages with ideologies of authenticity and the centralist ideology of the national standard language. It focuses on the ways in which this creative use of language by speakers from the periphery of the Serbian linguistic-cultural space repositions the already set ideological frames of urban-rural and local-national-global, and thus destabilizes the ideologically fixed relationship between the linguistic centre and the periphery.
\end{abstract}

Key words: dialect, creativity, Southeastern Serbia, periphery, urbanity, language ideology

E-mail address: tanjape@zrc-sazu.si 


\section{Introduction}

In the foreword of his seminal book on slang (Bugarski 2003), Ranko Bugarski emphasises that the linguistic approach to this phenomenon is capable of avoiding two extremes: "mere veneration of the linguistic creativity of youth without serious analysis, and technicist grammatical dissection of slang expressions" (p. 5). In this article, taking seriously his call not to uncritically or romantically venerate certain linguistic codes, I explore the nature of linguistic creativity in the linguistic practices of speakers from the Southeastern periphery of the Serbian linguistic space. Starting from Thurlow's (2010) assertion that the cultural politics of creativity unfolds in its capacity to engage with broader social and institutional practices and power relations, I see creativity in the strategic mixture of the local dialect with various discourses and explore the ways in which it engages with ideologies of authenticity and the centralist ideology of the national standard language. In the first section of the article, I outline the specific position Southeastern Serbia occupies in the Serbian linguistic landscape. In the following two sections, I analyse two linguistic practices marked by extensive use of the local dialect: the Facebook page Koe ima po grad ('What's up in the town'), an urban chronicle of Leskovac, and texts of the hip-hop band Southentik Crew from the town of Vlasotince. I focus on the ways in which this creative use of language by speakers from the periphery of the Serbian linguistic-cultural space repositions the already set ideological frames of urban-rural and local-national-global, and thus destabilizes the ideologically fixed relationship between the linguistic centre and the periphery.

\section{Serbia's Southeast and dominant linguistic ideologies in Serbian society}

Dialects spoken in Southeastern Serbia bear a heavy tinge of peripherality, ruralness, backwardness, and detachment from modernity. It is difficult, if not impossible, to articulate a neutral and anonymous statement (Woolard 2008) using such dialects, because they are perceived as "private and particular, rather than public and generic" (ibid., 305). For this reason, any ambition to participate in the public sphere and advance in the social hierarchy outside of the local setting is preconditioned by the shift from dialect to an idiom closer to the standard language. 
Tanja Petrović: Linguistic Creativity: A View from the Periphery...

Several linguistic-structural, geographical, historical, and cultural factors contribute to the construction of the peripherality of Southeastern Serbia and its dialects. The linguistic peripherality of the dialects is a consequence of their remoteness from the linguistic idioms in Serbia that are perceived as central and suitable for public use (the standard idiom, vernaculars spoken in Belgrade, and in western and northern parts of Serbia). In the South-Slavic dialectal continuum, dialects spoken in Southeastern Serbia are structurally and lexically closer to nearby Bulgarian and Macedonian dialects than to the northern and western dialects in Serbia that are the foundation for the Serbian standard language. These dialects belong to the East Balkan Slavic part of the Balkan Sprachbund and share many structural characteristics with Romanian, Albanian, and Greek dialects (Alexander 2000; Aronson 2007; Schaller 1975).

Cultural and historical factors also contribute to the peripherality of Southeastern Serbian dialects and the areas where they are spoken. As the Serbian territory where Ottoman rule lasted for a long time (Zlatanović 2003) and where the Ottoman legacy is still present in folklore and architecture, the "authentic Serbian identity" of Southeastern Serbia and its population has frequently been questioned. The region is often perceived as being "ambiguously Serbian" and thus opposed to Western Serbia and the parts of Montenegro and Bosnia and Herzegovina inhabited by Serbs. For example, in 1929, the Serbian poet Jovan Dučić wrote that it is "near Vranje where the epic wave is replaced by the lyric one." He describes Southeastern Serbia as an area dominated by feelings of sevdah (passion), dert (misery), and merak ${ }^{1}$ that are characteristic of the Middle East (Zlatanović 2009) and unknown in other Serbian regions. Dučić believed that dert is not a "Serbian feeling," and people who surrender to it are not Serbian enough, not even sufficiently Slavic. According to Dučić, "Marko Kraljević drinks, but does not fall into 'dert', and although Vranje is no longer Turkish, it remains at the gates of the Orient" (Dučić 1929). The "Serbian-ness" of language spoken in this area has also been frequently questioned: the entire history of Serbian dialectological research has been riddled with discussions about the proper classification of the dialects of Southeastern Serbia. Some dialectologists consider them a distinct group and call them the Torlak dialect group, placing these dialects at the same level as Štokavian, Kajkavian, and Čakavian dialects, while others argue

1 Dert (Persian) 'dolor', 'fatigue', 'misery'; merak (Arabian) 'joy', 'hedonism'; sevdah (Arabian) 'love', 'yearning', 'passion' (Škaljić 1966). 
that they are a subset of the Štokavian dialects (see Alexander 1975; Belić 1905; Ivić 1963, 1982; Toma 1998: 19-20; Rešetar 1907). In his Dictionary of the Serbian Language (1852), Vuk Stefanović Karadžić describes the term Torlak as "a person who speaks neither purely Serbian nor Bulgarian."

Moreover, Serbian society in general is characterized by a sharp contrast between centre and periphery in demographic and economic terms. Belgrade is the largest city in the country, several times larger than the other two largest cities, Niš and Novi Sad. According to the 2011 census, there were 1,344,844 inhabitants in Belgrade, 277,522 in Novi Sad, and 187,544 in Niš (Census 2011). Economic discrepancies are particularly noteworthy when it comes to the country's Southeast, where, according to Serbian National Television, monthly income is below the country's average (ca. 370 EUR), by up to 12,000 Serbian dinars (approximately 100 EUR), and the economic potential of the region is estimated to be eighty percent weaker than in Belgrade and northern parts of the country. ${ }^{2}$

The ambiguous position of Southeastern Serbia and its dialects in Serbian national imagery is closely related to the process of nation building, which is an essential component of European modernity. In accordance with the language ideologies that prevail in Serbia, the people who speak Southeastern dialects are perceived as rural and detached from modernity, despite the fact that Southeastern Serbia was intensively industrialized and urbanized in the second part of the 20th century and that one of Serbia's largest cities, Niš, is located in this region, along with several other large urban centres such as Leskovac, Vranje, Pirot, Zaječar (Petrović 2015). They share the "destiny" of many European local languages, that of being "tarnished with the image of the backward peasant who had failed to modernize with the rest of his or her neighbours" (Cavanaugh 2012: 15; see also Drysdale 2001; Kuter 1989; Timm 2001).

True, the urban life in Southeastern Serbia is often depicted in Serbian literature and filmography, but most of these stories take place during the Ottoman period and its immediate aftermath, and before the formation of the modern Serbian state. Borisav Stanković's (Vranje 1876 - Belgrade 1927) literary depictions of Vranje, and Stevan Sremac's (Senta 1855 - Sokobanja 1908) descriptions of the town of Niš belong to the Serbian literary canon. Stankovićs Koštana is the most frequently staged Serbian drama ever, and the films Zona Zamfirova (Šotra 2002) and Ivkova

2 <http://www.rts.rs/page/stories/sr/story/125/Društvo/2036770/Srpske+opštine, +što+ južnije+plate+niže.html> (15 September 2015, accessed 30 October, 2017). 
Tanja Petrović: Linguistic Creativity: A View from the Periphery...

Slava (Šotra 2005) based on Sremac's literary works are among the most popular Serbian films. They depict the cities of Southeastern Serbia as socially stratified, inhabited by people of many professions, ethnicities, and social backgrounds. The local language plays an important role in the depiction of the Oriental atmosphere, which is characterized by hedonism, strong emotions, singing, and dancing. However, these cities and indeed the whole region and the people inhabiting it, when depicted from a contemporary perspective through the lens of modernity, appear different: in these depictions, they have lost their Oriental allure and at the same time have failed to modernize. Speakers of Serbian Southeastern dialects are typically portrayed in popular culture, literature, and film (for example, in the film series Tesna koža and the television series Porodično blago, Bela lađa and Stižu dolari) as people who unsuccessfully aspire to higher social status. An iconic personification of such failed modernization is Srećko Šojić, a character featured in several television series and films from the 1980s onwards. Srećko Šojić is a unique character in the popular culture in Serbia because of his long filmic biography: this fictional character has appeared in television series and films over a period of over thirty years, from the movie Laf u srcu (Pavić 1981), to the popular film series Tesna koža (Pavić 1982-1992), to the recent television series Bela lađa (Pavić 2006-2012). Šojić is a morally corrupt, uneducated, and even grotesque businessman and politician who attempts to navigate the murky waters of the Serbian "transition" from socialism to democracy. ${ }^{3}$ Created by Siniša Pavić and interpreted by the actor Milan Gutović, Šojić comes "from the provinces" and is involved in dirty business (involving smuggling and corruption) and bizarre political projects (such as running the political Party of Common Sense). The fact that Šojić speaks a Southern dialect, in "a funny way" contributes to the peculiarity of his character and his failure to be a part of modern society.

Srećko Šojić is a popular culture character who epitomizes the ideological process in which the distinct and territorially defined way of speaking in Southeastern Serbia became an index of the social identity of lower uneducated social strata characterized by bad cultural taste and a lack of social skills. Linguists have focused on the relationship between

While many authors who deal with European post-socialism use the term transition neutrally (see e.g. Ekman \& Linde 2005), several others point to problematic political, ideological, and social aspects of this term and the logic behind it (Buden 2009; Horvat \& Štiks (eds) 2015). 
ways of speaking and social stratification since the pioneering research of Labov (1963, 1966, 1972) and Bernstein (1971, see Block 2014 for an overview). In the case of Southeastern Serbia, however, territorially defined dialects have been ideologically interpreted in social terms: all speakers of these dialects are perceived as linguistically and culturally homogeneous, regardless of their actual social and educational background (see also Pietikäinen \& Kelly-Holmes 2013: 2).

The authors of the Koe ima po grad Facebook page 4 and Southentik Crew lyrics write their texts against this ideological background, striving to depict and discuss the current reality of their respective cities (Leskovac and Vlasotince). These cities underwent intense industrialization during much of the 20th century, while the period of post-socialist transition that began in the early 1990s ushered in an era of deindustrialization along with a decline in living standards, suspicious privatizations, and the disintegration of urban infrastructure. These conditions and challenges define the reality of many mid-sized cities in post-Yugoslav societies, but the regions of Southeastern and Eastern Serbia were most severely hit. ${ }^{5}$ The devastated landscape of these areas has become a recognizable motif in recent Serbian cinematography: the films Tilva roš (Ležaić 2010) and Beli, beli svet (Novković 2010) are the most noteworthy examples.

\section{Koe ima po grad: Relocalization of dialect}

Koe ima po grad features visual material and witty texts filled with elements of local dialect. These texts and illustrations depict and discuss the "transitional" post-socialist reality of Leskovac and its inhabitants including shady privatizations, economic decline, dysfunctional municipal administration, environmental neglect and the dangers that accompany them, as well as the devastating consequences of poverty. Although this

4 I interviewed the author of posts at Koe ima po grad on several occasions during 2013 and 2014. He insisted on remaining anonymous. He is a university educated male in his early thirties who lives in Leskovac and works as a lawyer. For a detailed discussion of his linguistic strategies from the perspective of place-making, see Petrović (2018).

5 For a perspective on the disastrous dimensions of the late industrial condition in the cities and towns of Serbia along with other former Yugoslav republics and post-socialist countries see e.g. Berge (2012); Matošević \& Baćac (2015); Pelkmans (2013); Petrović \& Vukelić (eds. 2013); Petrović (2016); Potkonjak \& Škokić (2013). 
Tanja Petrović: Linguistic Creativity: A View from the Periphery...

Facebook page is seemingly a marginal and locally oriented phenomenon, it has attracted significant attention and acquired an audience well beyond the local context of Leskovac. From February 2011, when the site was created, until November 2017, it has gained more than 41,000 "followers", and the texts from the page are reposted on several electronic portals and news sites in Serbia such as <www.b92.net>, <www.e-novine.com>, $<$ www.juznevesti.com $>$, <www.leskovackevesti.rs $>$, <www.jugmedia.rs $>$, $<$ www.telegraf.rs $>,<$ www.vesti.rs $>$ etc. ${ }^{6}$ This suggests that these locally generated texts address issues that are recognizable and relevant to a wider audience in post-socialist Serbia.

The remoteness of the idioms spoken in Southeastern Serbia from the Serbian standard language informs their general perception as being "distorted" and thus funny. Both the particular lexical items and the structural features of these dialects contribute to this perception. The author of the Koe ima po grad texts makes ample use of the structural features of the local dialect (underlined in the examples below):

(1) Nakon što očistiv drljke od oči i obrnev jednu čašku prepek kreću na stanicu da ispaliv dve rakete koje gi je opština obezbedila za do kraj godinu.

[After they wipe the sleep from their eyes and drink one shot of brandy, (the technicians from the municipality) went to the anti-hail station to fire the two rockets that the municipality had acquired for protection until the end of the year. $]^{7}$

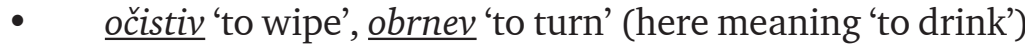
vs. standard Serbian očiste, obrnu;

- $\quad$ od oči vs. standard Serbian sa očiju 'from eyes';

- $\quad$ jednu čašku prepek 'one shot of brandy' do kraj godinu 'until the end of the year' vs. standard Serbian jednu čaš( $(k) u$ prepeka, do kraja godine;

- $\quad$ gi vs. standard Serbian im 'them'.

6 However, the author of the page has not been active recently, and the latest post is from October 2015.

7 <https://www.facebook.com/KoeImaPoGrad/posts/976998305668113:0> (posted 18 June 2015, accessed 3 November 2017). 
(2) Cveće u baštama je procvetalo i ljudi se polako prekačujev preko tarabe da ga obrstiv.

[Flowers bloom in gardens and people jump over the fences to pick them. $]^{8}$

- $\quad$ prekačujev 'to jump over', obrstiv 'to pick' vs. standard Serbian preskaču, obrste (or pokidaju 'to pull', since obrste 'browse' is used in the standard language only for animals feeding on plants)

(3) Na pijac je sve više ljudi. Početak proleća njima signalizira da treba da prestanev da jedev prženu papriku i ajvar iz teglu, jer će se uskoro na ovom mestu naći sveže prskani proizvodi.

[There are more and more people at the market. The beginning of spring signals to them that they should stop eating roasted peppers and ajvar from jars because soon they will be able to get produce freshly exposed to pesticides. $]^{9}$

- $\quad$ na pijac vs. standard Serbian na pijaci, 'at the market';

- $\quad$ da prestanev da jedev vs. standard Serbian da prestanu da jedu or da prestanu jesti, 'to stop eating';

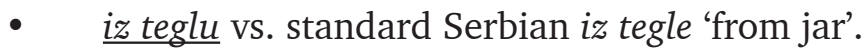

Texts with such lexical and structural dialectal features are "taken seriously" and perceived as authentic if they are in a context related to folk, rural, or pre-modern life, but provoke laughter as soon as they emerge in public communication or in situations characteristic of contemporary interactions. Humour is often based on incongruity, on the "difference between what people expect and what they get" (Berger 1995: 105). In the case of dialects spoken in Leskovac and Southeastern Serbia in general, humour, which is a constant in the perception of these idioms and the main characteristic of their social aesthetics, stems from the incongruity between their forms and the idea of the linguistic forms appropriate for contemporary public communication. This incongruity makes it difficult to articulate serious statements using dialect. According to dialectologist Nedeljko Bogdanović, "the [serious] prose written in this dialect is often on the edge of being transformed to its opposite" (Bogdanović 2006: 93).

8 <https://www.facebook.com/KoeImaPoGrad/posts/948382538529690:0> (posted 22 April, 2015, accessed 1 September 2016).

9 Ibid. 
Tanja Petrović: Linguistic Creativity: A View from the Periphery...

Bogdanović describes the situation in which "an author recited an elegiac story from his homeland, but the audience laughs at the local expressions and dialectisms, which are perceived as caricature" (ibid.).

Particular expressions, word play, and effective lexical combinations are characteristic of both everyday language use and the rich literary production in dialect. This includes novels, short stories, poetry, and satirical texts written by local authors. However, a great deal of this literature is restricted by the widespread perception of "folk identity", and a language ideology that can be found in ethnographic and folkloristic literature (Plas 2007), which sees the use of dialect as authentic because of its local nature (Woolard 2008). Although such language ideology gives local dialect authority based on authenticity (Gal \& Woolard 2001: 7), the dialect remains incapable of entering the public sphere on either local or national level and articulating messages related to the current reality of Southeastern Serbian cities and its citizens.

The author of the texts published at the Koe ima po grad Facebook page, however, manages to explicitly address issues and problems that significantly shape Leskovac's present and succeeds in escaping the limitations established by an ideology of authenticity in which the use of dialect implies a close relationship between a language and a distinct community, locality (usually meaning rural community), and a nostalgic gaze toward the past. He does so by combining elements of local dialect and local geographical references with fixed, recognizable, and welldefined genres that circulate in the public sphere in standard language (e.g. newspaper reports, fairy tales, descriptions in tourist guides, scientific descriptions of species). For example, he presents localized - both linguistically and thematically - versions of the fairy tales Beauty and the Beast, ${ }^{10}$ Three Little Pigs, ${ }^{11}$ The Princess and the Pea, ${ }^{12}$ The Emperor's New Clothes ${ }^{13}$ and Sleeping Beauty. ${ }^{14}$ The tales are situated in Leskovac, written

10 <https://www.facebook.com/KoeImaPoGrad/posts/806107359423876:0> (posted 6 August 2015, accessed 3 November 2017).

11 < https://www.facebook.com/notes/362923340408949/> (posted 7 March 2012, accessed 3 November 2017).

12 < https://www.facebook.com/KoeImaPoGrad/posts/469398293094786:0> (posted 20 September 2012, accessed 25 March 2016).

13 < https://www.facebook.com/KoeImaPoGrad/posts/839811492720129:0> (posted 8 October 2014, assessed 3 November 2017).

14 < https://www.facebook.com/KoeImaPoGrad/posts/753659601335319:0> (posted 30 April 2014, assessed 3 November 2017). 
in a combination of standard Serbian language and Southeastern Serbian dialect, clearly articulated in the genre of fairytales with typical formulae (bold in the Example 4, dialect underlined), and finally replete with references to the grim reality of everyday life in the impoverished region of Southeastern Serbia. Sleeping Beauty begins in the following way:

(4) Nekada davno živeli su kralj i kraljica u Garetovu palatu. Kupiše stan na kredit. Posle mnogo godine rodi gim se ćerka, a još ni pola kredit nesu vrnuli. Nemav pare, koe će radiv, napraviše slavlje. Za sedamsto duše. Dodjoše svi iz Leskovac kravaj da donesev.

[Once upon a time, there were a king and a queen who lived in the Gare Palace. They took out a mortgage on the palace. After many years, they gave birth to a daughter, but they still had half of the mortgage to pay off. They had no money, so what would they do, they decided to throw a party. For seven hundred people. Everyone from Leskovac came and brought the ritual bread. ${ }^{15}$

- $\quad$ u Garetovu palatu vs. standard Serbian u Garetovoj palati 'in the Gare palace';

- $\quad$ posle mnogo godine vs. standard Serbian posle mnogo godina 'after many years';

- $\quad$ gim vs. standard Serbian im 'them';

- $\quad$ nesu vrnuli vs. standard Serbian nisu vratili 'did not give back' (here: 'did not pay off');

- $\quad$ nemav pare vs. standard Serbian nemaju para; 'do not have money';

- $\quad$ koe će radiv vs. standard Serbian šta da rade; 'what will they do';

- $\quad$ sedamsto duše vs. standard Serbian sedamsto duša; 'seven hundred souls (meaning people)';

- $\quad$ iz Leskovac vs. standard Serbian iz Leskovca 'from Leskovac';

- $\quad$ donesev vs. standard Serbian donesu 'bring'.

15 Ibid. 
Tanja Petrović: Linguistic Creativity: A View from the Periphery...

When the princess reaches her sixteenth birthday, she falls asleep inside the dilapidated complex of the factory once renowned for its textile production. A prince arrives on a powerful Yamaha motorcycle and rescues the princess. They open a disco club on the premises of the factory and live happily ever after, that is until the State Agency for Privatization comes and kicks them out.

The website also features a text in the form of a tourist advertisement for the Morava River valley, in which the author ironically exposes the pollution and neglect of the river which is the only summer destination that many of the inhabitants of Leskovac can afford. In this text, he also combines dialect and local references with expressions in the standard Serbian language that situate the text in the genre of the tourist advertisement (bold in Example 5):

(5) Ne propuštite Moravu ni ovoj leto. Ovaj prijatni zmijarnik oduvek je bio zbirište za elitni slojevi Jablaničkog okruga. Brojne vikendice na Crveni Breg ugostiće i ovej godine mnogi tajkuni iz Grajevce $i$ Zlokućane. Očekuje se i pojačan priliv stranih turista iz Frankfurt, Beč, Lucern i Čikago, svi rodom iz Malu Kopašnicu.

[Do not miss the Morava River this summer. This pleasant snake pit has always attracted elite members from Jablanovac County. Many weekend houses on Crveni Breg will host tycoons from Gajevica and Zlokućane this year, too. An influx of foreign tourists from Frankfurt, Vienna, Luzern and Chicago is also expected, all of them originating from Mala Kopašnica (= "Gastarbeiters") $]^{16}$

- $\quad$ propuštite vs. standard Serbian propustite 'miss';

- $\quad$ ovoj vs. standard Serbian ovo 'this';

- $\quad$ zbirište vs. standard Serbian stecište 'place of gathering';

- $\quad$ za elitni slojevi vs. standard Serbian za elitne slojeve 'for elite society layers';

- $\quad$ na Crveni Breg vs. standard Serbian na Crvenom Bregu 'on Crveni Breg';

- $\quad$ ovej vs. standard Serbian ove 'these';

16 <https://www.facebook.com/notes/koe-ima-po-grad/last-minute-ponuda/ 458879527479996> (posted 23 August 2012, accessed 3 November 2017). 
- $\quad$ mnogi tajkuni vs. standard Serbian mnoge tajkune 'many tycoons';

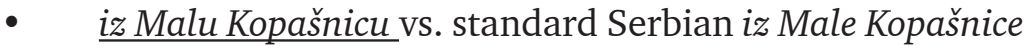
'from Mala Kopašnica'.

One of the texts addresses the invasion of mosquitoes in summer months. The scientific descriptions of mosquito's morphology and biotope in standard language (bold in the Example 6) are combined with expressions in dialect (underlined), expressions and forms typical of casual oral communication (marked with double underlining), local geographical references, and witty mocking of the city authorities for their failure to effectively prevent the spread of the insects:

(6) Komarci (familija Culicidae) - vrsta insekata koja tokom letnji' meseci pije krv na narod 'mesto političari koji su na odmor. Sasvim neopravdano svrstani su u red dvokrilaca jer ovija naši garant imav po pešes' krila - ne mož gi čovek utepa kol'ko begav.

[Mosquitos (family Culicidae) - a species of insects that suck blood from human beings in the summer months, thus replacing politicians who go on vacation at that time. They are classified as two-winged insects, which is unjustified, because ours surely have five or six wings which make them so quick that they cannot possibly be caught and killed.] ${ }^{17}$

- $\quad$ na narod vs. standard Serbian narodu 'people' (here: 'humans');

- $\quad$ na odmor vs. standard Serbian na odmoru 'on vacation';

- $\quad$ ovija vs. standard Serbian ovi 'these';

- $\quad$ utepa vs. standard Serbian ubije 'kill';

- $\quad$ begav vs. standard Serbian beže 'run/fly away';

- $\quad$ letnji 'vs. standard Serbian letnjih 'summer';

- $\quad$ 'mesto vs. standard Serbian umesto 'instead';

- garant vs. standard Serbian sigurno, svakako 'surely, certainly';

17 < https://www.facebook.com/KoeImaPoGrad/posts/776028175765128:0> (posted 11 June 2014, accessed 3 November 2017). 
Tanja Petrović: Linguistic Creativity: A View from the Periphery...

- $\quad$ pešes'vs. standard Serbian pet-šest 'five-six';

- $\quad \underline{\text { kol'ko }}$ vs. standard Serbian koliko 'how much'.

Koe ima po grad texts, with their combination and mixing of seemingly incompatible codes - local dialect with expressions typical of oral communication and "cosmopolitan" genres in the standard Serbian language such as that found in tourist advertisements, (Disney) fairy tales, and scientific descriptions of species - are thus dialogic and intertextual (see Bakhtin 1981; Pennycook 2010), and provide a way to re-localize the dialect. Elements of the local dialect are framed by recognizable or fixed genre forms that are closely linked both to standard language and to supralocal and public realms of communication. In this context, they become detached from the previous dominant representations of ruralism, locality, backwardness, and bizarreness, and re-linked to the local urban, transitional, post-industrial, hybrid, and fluid reality of Leskovac. Strategic appropriation and combination of "discursive conventions, codes and elements in new ways in innovatory discursive events" produce "structural changes in orders of discourse" (Fairclough 1992: 97). This is a well-documented strategy employed in different domains of language use. For example, Bhatia (2008) reports on the strategic mixing of the discourses of law, accounting, finance, and public relations in corporate disclosure reports.

\section{Southentik Crew: Globalizing the local}

As a global musical phenomenon, hip-hop is tightly connected to perceptions of marginality and peripheriality. With its roots in the USA of the 1980s, where it was a musical idiom of urban ghettos and economically deprivileged Afro-American population (see Banić Grubišić 2013, Kelner 2004: 297), hip-hop is today perceived as a global musical voice of the excluded and discriminated, whereby performance characteristics and songs' themes share many features, regardless of the concrete language in which they are created. This global character of hip-hop significantly contributes to the mobilizing potential of the genre, because it offers to the authors a language for universally recognizable articulation of local narratives on inequality and exclusion, and simultaneously provides a possibility for inclusion into broader social frames and flows. That is why it comes as no surprise that hip-hop is an important musical genre in 
contemporary Serbia (see Nenić 2006, Banić Grubišić 2013, Vojnov 2004). For the same reasons, hip-hop has become a critically important way of expressing the cultural identity of young people at different peripheries of the Serbian society - particularly in its southeast. ${ }^{18}$

This, however, by no means implies that hip-hop does not have its own "mainstream": it gives a voice to those on the periphery or the margin, but it can simultaneously be a means of affective mobilization of those in the centre. The band Beogradski sindikat is an example of such mobilization. A comparison of Beogradski sindikat's repertoire with songs of another renowned representative of the Serbian hip-hop scene, Marčelo, offers an insight into the logics of how centrality vs. marginality of linguistic idioms governs hip-hop production in Serbia. Beogradski sindikat uses recognizable Belgrade slang. This idiom may be considered marginal in relation to the Serbian standard, but in the songs of Beogradski sindikat it is a "voice of Serbia" and a linguistic expression of national - and often nationalistic ideology. On the other hand, Marčelo's songs articulate a sharp critique of nationalism and related phenomena in Serbian society; he performs in a non-localized, neutral and standard idiom. Marčelo is from Paraćin, but there are no traces of local idiom in his lyrics. He articulates his social critique in a neutral and authoritative language, because it would lose legitimacy if articulated in his local idiom. Despite the marginality of (any) slang as a subcultural idiom, Beogradski sindikat's messages do not suffer legitimation loss - their "Belgradeness" secures their ideologically central position, necessary for the articulation of nationalistic narratives, as well as for their deconstruction.

Although an essentially global phenomenon that can serve as a tool for expression of views from the central/majority position, the key-element in the hip-hop production is its connection to the local: hip-hop is "the most local" modern form of expression (Banić Grubišić 2013, 120) and a tool for negotiation of local identity (Pennycook 2007). For this reason, theoreticians of culture who have studied hip-hop dedicate a lot of attention to dialectics between the local and the global, describing it by means of terms such as glocalization, musical transculturation or re-territorialization (Banić Grubišić 2013: 118; see also Nenić 2006: 160, Pennycook 2007, Androutsopoulos 2003).

18 Hip-hop authors from Southeastern Serbia often emphasise the parallel between (African American) South of the USA and the south of Serbia (e.g. name of the band Southentik Crew, the song Ovo je jug ('This is south') by the group N1H1 etc.). 
Tanja Petrović: Linguistic Creativity: A View from the Periphery...

In the case of hip-hip production in Southeastern Serbian urban settings, however, transposition of global patterns into local frames faces several challenges that result from the workings of the dominant language ideologies: here, the notion of the local is not homogeneous, unambiguous and "empty." Prevalent ideologies and power relations are already inscribed into this notion. Using dialect as one of the most salient markers of local identity, hip-hop authors must deal with already fixed meanings of dialects and frames of circulation of dialectal elements.

The hip-hop band Southentik Crew from Vlasotince released an album entitled Najgore iz vlasotinačku kanalizaciju ('The worst from the Vlasotince sewer') in 2012. Local language features are present in this album at the prosodic, phonological, morphological and lexical levels. Explicit metapragmatic comments often point to these elements. These comments address language, and way of speaking/singing. ${ }^{19}$ The opening song Vlasotince slang like dis ('Vlasotince slang like this') is an example of such explicit positioning toward language/dialect. According to the authors, this song is "a tribute - remix of P-Money's song Slang like this and was made to represent the southern way of speaking. People from different countries have already made remixes, a Serbian remix also exists, so it was time to make a Vlasotince remix". ${ }^{20}$ The opposition between the Serbian and the Vlasotince language in this statement appears in the lyrics of the song several times (underlined dialectal lexicon or elements; double underlined are expressions and forms typical of casual oral communication):

(7) Ovo je druga država iako ne'amo pasoši

[This is a different state although we have no passports] ${ }^{21}$

- $\quad \underline{\underline{\text { ne'amo }}}$ vs. standard Serbian nemamo 'we do not have'

- $\quad$ pasoši vs. standard Serbian pasoše 'passports'

19 Metapragmatic comments can be explicit, in those cases when a speaker comments on her or his language use or language use by others, when (s)he directly refers to particular speech events and dicourse segments, justifying, assessing and defining them by genre (see Lucy 1993, 17, Urban 1984), or implicit, which are contained in the very choice of language elements and in signals given by a speaker to interlocutors, suggesting how these elements should be understood (Lucy 1993).

20 https://www.youtube.com/watch?v=vuJy-ri2mMo, accessed 3 November 2017.

${ }^{21}$ Transcripts of the lyrics are taken from the "subtitles" embedded in video clips published on YouTube channel Black planet record Srbija (https://www.youtube.com/ watch?v=6iDZTZLVSZw; https://www.youtube.com/watch?v=qm-IUve0R4g), so the written form of lyrics is presented here according to authors' own representation. 
(8) Vi ste sa juga? Ne, mi smo sa zastavu / vlasotinački uključujemo u nastavu

[Are you from the south? No, we came by Zastava / we introduce the Vlasotince language in curriculum]

- $\quad$ sa zastavu vs. standard Serbian sa zastavom 'with the Zastava car' (the pun is based on the reinterpretation of the standard Serbian sa juga 'from the south', where the form sa juga is homonymous to the local dialect form 'with the Yugo car'; cf. mi nesmo s autobus, mi smo Southentik 'we did not come by bus, we are Southentik' in the song Hejteri ranimo s gomna)

With these lines, the authors oppose hegemonic views from the centre bringing their own dialect into hip-hop discourse. That act of opposition (in this song effectively described as introducing Vlasotince language in curriculum) is inevitably faced with two challenges set by fixed perceptions and evaluative attitudes toward language in Serbian society: the first is conditioned by the ideology in which the dialect of Southeastern Serbia is an index of ruralness and premodernity, and the second stems from the perception of these dialects as comic, funny and bizarre.

One of the ways to respond to these challenges is to emphasize competence in the local dialect as a specific kind of knowledge and virtue that is not available to everyone. The unintelligibility of a dialect is often a reason for marginalization, as described in the following line of Vlasotince slang like dis:

(9) K'd otidnem na stranu, ne znam kvo da rabotim / nikoj ne razbira kad počnem da lomotim

[When I go somewhere else, I do not know what to do / no one understands me when I start speaking fast $]^{22}$

- $\quad \quad \quad \quad$ 'd vs. standard Serbian kad 'when'

- $\quad \underline{k v o}$ vs. standard Serbian šta 'what' (contracted form of dialectal kakvo 'what')

- $\quad$ rabotim vs. standard Serbian radim 'do'

- $\quad$ nikoj vs. standard Serbian niko 'nobody'

- $\quad$ razbira vs. standard Serbian razume 'understand'

- $\quad$ lomotim vs. standard Serbian govorim brzo 'speak fast'

22 https://www.youtube.com/watch?v=vuJy-ri2mMo, accessed 3 November 2017. 
Tanja Petrović: Linguistic Creativity: A View from the Periphery...

However, the authors turn this way of speaking into their own advantage, and see the unintelligibility of their idiom not only as a consequence of its remoteness from the standard, but also as a result of their fast way of speaking and linguistic creativity. Thus, it becomes a tool of self-positioning vis-a-vis the hegemonic centre:

(10) Mno'o mi se ti razmišljaš kolko sam ja pismen / al' i toj ću ti pokažem preko usta kad te šlijsnem / Ja tebe sve razumem a ti mene ni osminu

[You think too much about how literate I am / but I will show you that when I hit you to the mouth / I understand everything you say, and you cannot understand even one eighth of what I am saying $]^{23}$

- $\quad$ mno'o vs. standard Serbian mnogo 'much, a lot'

- $\quad \underline{\underline{k o l k o}}$ vs. Standard Serbian koliko 'how much'

- $\quad$ toj vs. standard Serbian to 'that'

- $\quad$ šljisnem vs. standard Serbian udarim 'hit'

A reviewer of the Najgore iz vlasotinačku kanalizaciju album interprets their linguistic choices in a similar vein: "The advantage of these rappers is in their language and dialect choice, complex meanings of their expressions and their newly-coined words. If you watch (...) their videos which have lyrics added, you understand what they say only at least 3-4-5-6 beats later. If you can understand what they are talking about at all. They are elusive, fast, eloquent, intelligent..." ${ }^{\prime 24}$

Another, and for our discussion on linguistic creativity the most important strategy used to challenge dominant language ideologies in Southentik Crew's song is strategic combination of diverse discursive frames, through which the authors directly link local dialectal elements (underlined in examples 11-14) with elements from the global hip-hip vocabulary, globalized youth slang and other global references (bold in examples 11-14):

${ }^{23}$ https://www.youtube.com/watch?v=vuJy-ri2mMo, accessed 3 November 2017.

24 http://www.terapija.net/mjuzik.asp?ID=17371, accessed 31 October, 2017. 
(11) obukujem genksta kariranu košulju [I put on a gengsta chequered shirt] ${ }^{25}$

- $\quad$ obukujem vs. standard Serbian oblačim 'dress, put on'

(12) original južnjak, kažu mi da sam seljak / lejzi strogo kežual, doesn't give a fuck

[an authentic Southerner, they tell me I am a peasant (nonsophisticated person) / lazy strict casual, doesn't give a fuck $]^{26}$

(13) Nikad ništa đuture, sve isplanirano, (...) pesme snimujemo [we do nothing ad-hoc, everything is well planned (...) we record songs] ${ }^{27}$

- $\quad$ duture vs. standard Serbian bez merenja/brojanja 'without mesuring/counting, ad hoc'

- $\quad$ snimujemo vs. standard Serbian snimamo 'record'

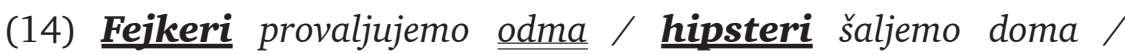
Southentik in da house, utepujemo odma

[Those who are fake we figure out right away / hipsters we send home / Southentik in da house, we beat up right away] ${ }^{28}$

- $\quad$ Fejkeri vs. standard Serbian fejkere 'fakers'

- $\quad \underline{\text { odma }}$ vs. standard Serbian odmah 'right away'

- $\quad$ hipsteri vs. standard Serbian hipstere 'hipsters'

- $\quad$ utepujemo vs. standard Serbian prebijamo 'beat up'

Not only do the authors bring together local dialect and global hip-hop discourses, but they also challenge other hegemonic discursive relations, such as the "mainstream" hip-hop discourse, using dialectal forms of hiphop vocabulary (e.g. snimujemo in Example 13, fejkeri, hipsteri in Example 14) and putting global references in direct contact with local, structurally and prosodicaly marked forms, as in the Examples 11 and 12.

\footnotetext{
25 https://www.youtube.com/watch?v=vuJy-ri2mMo, accessed 3 November 2017.

26 https://www.youtube.com/watch?v=qm-IUve0R4g, accessed 3 November, 2017.

27 Ibid.

28 Ibid.
} 
Tanja Petrović: Linguistic Creativity: A View from the Periphery...

Such a strategy enables the authors to avoid self-positioning along the nationally defined dichotomy between the centre and the periphery that locates local idiom into clearly defined interpretational schemes - as rural, pre-modern, bizarre, or funny. However, they do not totally reject the recognizable lexical repertoire indexical for the Serbian south and its language. In the refrain of the song Vlasotince slang like dis there is an inventory of local addresses and other dialectal elements which unambiguously position this music into the local context: A prike (kvo?), snajke (kude?), bracke (z'što?), d'ugare (eve) / rođo (kam si?), vuči (koje?), Vlasotince slang like dis! Such lexical choice simultaneously localizes and globalizes Vlasotince as an urban space. It also serves as a tool to negotiate positioning of the local cultural space and its idioms outside the fixed centre vs. periphery dichotomy, or to directly oppose it.

\section{Conclusion: Linguistic creativity and dialect use}

The two practices of local dialect use discussed in this paper - the Facebook chronicle Koe ima po grad and lyrics of the hip-hop band Southentik Crew - significantly rely on strategic combination of linguistic elements indexing locality with global references. While in the case of hip-hop lyrics this global-local syncretism (Lee 2010; Pennycook 2009, 2010) mainly concerns lexical elements, in the case of the Koe ima po grad texts, the local lexical elements are combined with discursive genres that typically do not tolerate local, vernacular, dialectal expressions. The author of the Koe ima po grad posts addresses local events and problems, and his texts abound with local references and toponyms. In a similar vein, Southentik Crew construes Vlasotince as an urban space by using very local expressions. In this way, the local dialect is transformed into an appropriate code to address actual, present-day urban reality, but does not lose its perceived authenticity stemming from its firm connection to the local. As such, these practices may be understood as place-making practices in which images of the cities of Leskovac and Vlasotince are created outside the fixed frame set by dominant language ideologies.

In both discussed cases, the authors are perceived by readers/listeners as creative and skillful users of language. Stylization and the creative use of language are usually understood as an antipode to authenticity (Hockett 1963; Coupland 2001), as they involve multiple filters and 
levels of representation (Bell 1991). The texts published at Koe ima po grad and Southentik Crew's lyrics are the product of stylization, but they do not entirely ignore the ideology of authenticity because they are both created and received in connection to a particular community - the inhabitants of respective cities. These texts rely on what we may call "the authentic meaning" (Coupland 2001: 414) of local linguistic forms. They simultaneously challenge the dominant language ideology in Serbia and hinge upon it. ${ }^{29}$ This complex relationship between the linguistic strategies and the dominant ideology prompts the question of the nature of the creativity from which the texts emerge.

The authors' use of elements from the local dialect, and the combining of these elements with recognizable genres and global hip-hop vocabulary is very different from the creative and authentic use of dialect described by dialectologists and others engaged in the study of "folk culture" (Plas 2007). Usually, the ability to use dialect creatively is focused on the creative properties of the products, i.e. the texts (Jones 2010: 5), and not seen as a special capacity of all people, but rather as a capacity of special people (ibid.: 2). These special people are typically elderly speakers with little or no education, but with "natural wisdom" and some literary talent. The Serbian dialectologist Prvoslav Radić describes this romanticized authentic creativity as follows: "An important part of the folk spirit is language in all its forms, including its epic and lyric dimensions - they reveal the narratives of speakers as true artistic works" (Radić 2010: 12). The creative speaker of a dialect is conceived as absolutely isolated from the standard language and other codes and genres that circulate in the social space outside of the local setting.

Such an understanding of the creative use of local dialects has roots in the process of nationalization that started in Southeastern Europe at the end of 19th and the beginning of the 20th century (Rihtman-Auguštin 2001), and should be understood as "part of a programmatic dialogue between the institutional-scholarly center and the rural periphery" (Plas 2007: 2250). Through this dialogue, the creative speaker of a dialect is constructed from above, from the perspective of members of the elite who are cosmopolitan and therefore capable of moving between codes and social settings. In contrast, authentic creative users of dialect need to be socially

29 On such dual position of local idioms towards centrist ideology and normativity, see also Heller (2006); Jaffe (2000); Moore, Pietikäinen \& Blommaert (2010); Pietikäinen \& Kelly-Holmes (2011, 2013). 
Tanja Petrović: Linguistic Creativity: A View from the Periphery...

immobile and fixed in their pre-modern and rural locality. The creative use of dialect in literary production follows this ideological pattern to a great extent: it remains thematically constrained to rural life and locally oriented, which leads to its marginalization. This literature is "either less valued, or seen as an expression of a lack of trust in the standard language" (Stanonik 2007: 467), because it remains outside the cosmopolitan, fluid, and hybrid reality of modern life.

Creativity in the use of dialect by the author of the Koe ima po grad texts and Southentik Crew's lyrics is of a very different kind. This creativity does not draw on what is unique and new in dialectal expressions, but on the process of putting what is ordinary and familiar in the local idiom in dialogue with existing and easily recognizable lexical elements and discursive genres circulating in discursive spheres beyond the local. Understood in this way, creativity is not merely an innovative attitude toward the language that remains within the confines of a single communication code. It is revealed on points of the intersection between different codes, and within local, national, and global communication frames. As Negus and Pickering (2004: 68) point out, creativity "is about giving form to the material we draw on and transform, and this cannot be done without reference to existing rules, devices, codes and procedures." The transformations that underlie creativity "occur not only through great works of art of paradigm-changing scientific discoveries, but also through the incremental everyday actions of individuals as they strategically appropriate and combine elements of different 'Discourses' in order to meet the needs of particular moments" (Jones 2010: 8; see also Bohm 1998; Pennycook 2010).

The essential question to ask is how these texts "are used to take actions in broader socio-cultural contexts" (Jones 2010: 4). Do the Koe ima po grad texts and Southentik Crew's lyrics, based on the strategic combination of various discourses that allows for the reappropriation and relocalization of the dialects of Leskovac and Vlasotince, have the potential to open up possibilities for "the imagining of new kinds of social identities and new kinds of social practices" (Jones 2010a)? The authors of these texts, through a complex relationship with the centralist nationallyframed language ideology that demotes the local dialect to the level of funny, bizarre, rural, low-culture and backward, manage through the combination of dialect with recognizable genres and discourses to take the local idiom out of its fixed ideological frame, "normalize" it, and make it appropriate for use in diverse realms of communication. These processes 
provide citizens of Leskovac and Vlasotince (and Southeastern Serbia in general) with the potential to reappropriate their local idiom, which in turn becomes an effective medium for place-making and the ability to imagine local reality outside the predictable folkloristic or rural frames. Leskovac and Vlasotince depicted in the Koe ima po grad texts and Southentik Crew's lyrics are places deeply rooted in contemporary reality. They emerge in these texts as places defined by the local, real, and symbolic geographies; the local idiom used in them serves as a tool that enables speakers to maintain an "intimate, lived relationship with their language" (Cavanaugh 2012: 12).

\section{References}

Alexander, R. (1975). Torlak Accentuation. Munich: Otto Sagner.

Alexander, R. (2000). Bosnian, Croatian, Serbian: A Grammar with Sociolinguistic Commentary. Madison WI: The University of Wisconsin Press.

Androutsopoulos, J. (2003). Einleitung. In: Androutsopoulos, J. (ed.), HipHop: Globale Kultur - Lokale Praktiken. Bielefeld: Transcript Verlag, 9-23.

Aronson, H. (2007). The Balkan linguistic league, "orientalism," and linguistic typology [The Kenneth E. Naylor Memorial Lecture Series, No. 4]. Ann Arbor MI: Beech Stave Press.

Bakhtin, M. (1981). The Dialogic Imagination: Four Essays. Austin TX: University of Texas Press.

Banić Grubišić, A. (2013). Romski hip hop u Srbiji: Muzika i konstrukcija manjinskog identiteta. Beograd: Srpski genealoški centar, Odeljenje za etnologiju i antropologiju.

Belić, A. (1905). Dijalekti istočne i južne Srbije. Srpski dijalektološki zbornik I, Belgrade: Serbian Academy of Sciences and Arts.

Bell, A. (1991). The Language of News Media. Oxford: Blackwell.

Berge, T. (2012). The worse, the better. On safe ground in "The Most Polluted Town on Earth." Anthropological Journal of European Cultures 21(1): 81-102.

Berger, A. A. (1995). Blind Men and Elephants: Perspectives on Humor. New Brunswick NJ: Transaction Publishers. 
Tanja Petrović: Linguistic Creativity: A View from the Periphery...

Bernstein, B. (1971). Class, Codes and Control, Vol. 1: Theoretical Studies Towards Sociology of Language. London: Routledge and Kegan Paul.

Bhatia, V. (2008). Creativity and accessibility in written professional discourse. World Englishes 27(3-4): 319-326.

Block, D. (2014). Social Class in Applied Linguistics. London: Routledge

Bogdanović, N. (2006). Iz recenzije. In Radiša Dragićević, Na drugoj obali. Bor: Bakar.

Bohm, D. (1998). On Creativity. London: Routledge.

Buden, B. (2009). Zone des Übergangs: Vom Ende des Postkommunismus. Frankfurt: Suhrkamp.

Bugarski, R. (2003).Žargon. Belgrade: XX vek.

Cavanaugh, J. (2012). Living Memory: The Social Aesthetics of Language in a Northern Italian Town. Malden MA: Wiley-Blackwell.

Census (2011). 2011 Census of Population, Households and Dwellings in the Republic of Serbia. Belgrade: Statistical Office of the Republic of Serbia.

Coupland, N. (2001). Stylization, authenticity and TV news review. Discourse Studies 3(4): 413-442.

Drysdale, H.(2001). Silenced for liberated: Endangered languages within The European Union. In: C. Moseley, N. Ostler, H. Ouzzate (eds.), Endangered Languages in the Media: The Proceedings of the Fifth Foundation for Endangered Languages Conference. Bath: Foundation for Endangered Languages, 124-130.

Dučić, J. (1929 (1970)). Borisav Stanković. In Borisav Stanković, Nečista $k r v, 277-278$. Belgrade: Prosveta.

Ekman, J. \& J. Linde (2005). Communist nostalgia and the consolidation of democracy in Central and Eastern Europe. Journal of Communist Studies and Transition Politics 21(3): 354-374.

Fairclough, N. (1992). Discourse and Social Change. Cambridge: Polity.

Heller, M. (ed.) (2006). Bilingualism: A Social Approach. Houndmills: Palgrave Macmillan.

Hockett, C.(1963). The problem of universals in language. In: J. Greenberg (ed.), Universals in Language.Cambridge MA: The MIT Press, 1-29.

Horvat, S.\& I. Štiks (eds.) (2015). Welcome to the Desert of Postsocialism: Radical Politics after Yugoslavia. London: Verso.

Gal, S.\& K. Woolard (2001).Constructing Languages and Publics: Authority and Representation. In: S. Gal \& K. Woolard (eds.), Languages and 
Publics: The Making of Authority. Manchester UK - Northampton MA: St. Jerome Publishing, 1-12.

Ivić, P. (1963). O klasifikaciji srpskohrvatskih dijalekata. Kniževnost i jezik 1: 25-37.

Ivić, P. (1982). Književni i narodni jezik kod Srba. Istorija srpskog naroda II. Belgrade: Srpska književna zadruga, 519-534.

Jaffe, A. (2000). Introduction: Non-standard orthography and non-standard speech. Journal of Sociolinguistics 4(4): 497-513. doi: 10.1111/14679481.00127

Jones, R. (2010). Introduction: Discourse and creativity. In: R. Jones (ed.), Discourse and Creativity. Harlow: Pearson, 1-13.

Jones, R. (2010a). Creativity and discourse. World Englishes 29(4): 467-480.

Kelner, D. (2004). Medijska kultura. Beograd: Clio.

Kuter, I. (1989). Breton vs. French: Language and the opposition of political, economic, social and cultural values. In: N. Dorian (ed.), Investigating Obsolescence: Studies in Language Contraction and Death. Cambridge: Cambridge University Press, 75-90.

Labov, W.(1963). The social motivation of a sound change. Word 19: 273-309.

Labov, W. (1966). The Social Stratification of English in New York City. Washington DC: Center for Applied Linguistics.

Labov, W. (1972). Language in the Inner City. Philadelphia PA: University of Pennsylvania Press.

Lee, J. S. (2010). Glocalizing "Keepin It Real": South Korean hip-hop playas. In M. Terkourafi (ed.), Languages of Global Hip-Hop. London: Continuum, 139-161.

Ležaić, N. (2010). Tilva Roš. Serbia.

Lucy, J. (1993). Reflexive Language and Human Disciplines. In: John Lucy (ed.), Reflexive Language: Reported Speech and Metapragmatics. Cambridge: Cambridge University Press, 9-32.

Matošević, A. \& E. Baćac (2015). Kamena vuna prijepora: Suživot s tvornicom Rockwool na Pićanštini. Etnološka tribina 38(45): 139-149.

Moore, R. E., Pietikäinen S. \& J. Blommaert (2010). Counting the losses: Numbers as the language of language endangerment. Sociolinguistic Studies 4(1): 1-26.

Negus, K. \& M. Pickering (2004). Creativity, Communication and Cultural Value. London: Sage.

Nenić, I. (2006). Politika identiteta u srpskom hip hopu na primeru grupe Beogradski sindikat. TkH: Journal of Performing Arts Theory 11, 159-166. 
Tanja Petrović: Linguistic Creativity: A View from the Periphery...

Novković, O. (2010). Beli, beli svet (Serbia).

Pavić, S. (1981). Laf u srcu (Serbia).

Pavić, S. (1982-1992). Tesna koža (Serbia).

Pavić, S. (2006-2012). Bela lađa (Serbia).

Pelkmans, M. (2013). Ruins of hope in a Kyrgyz post-industrial wasteland. Anthropology Today 29(5): 17-21.

Pennycook, A. (2007). Language, localization, and the real: Hip-hop and the global spread of authenticity. Journal of Language, Identity and Education 6(2), 101-115.

Pennycook, A. (2009). Refashioning and performing identities in global hip-hop. In: N. Coupland \& A. Jaworski (eds.), The New Sociolinguistics Reader. Houndmills: Palgrave Macmillan, 326-347.

Pennycook, A. (2010). Language as a Local Practice. London: Routledge.

Petrović, T. (2015). Srbija i njen jug: "Južnjački dijalekti” između jezika, kulture i politike. Belgrade: Fabrika knjiga.

Petrović (2016). Divided modernities: Citizenship, agency and public spaces in a Central Serbian Town. Etnološka tribina 39(46): 111-125.

Petrović, T. (2018). What's up in town: Place-making through the use of dialect in a Facebook chronicle of Leskovac (Southern Serbia). In: L. Cornips. \& V. de Rooij (eds.), The Sociolinguistics of Place and Belonging: Perspectives from the Margins. Amsterdam: John Benjamins, 179-206.

Petrović, M. \& J. Vukelić (eds). (2013). Environmental Protection in Pančevo and Bor: Challenges of Participation to Environmental Governance. Belgrade: Institute for Sociological Research, Faculty of Philosophy, University of Belgrade.

Pietikäinen, S. \& H. Kelly-Holmes (2011). Gifting, service and performance: Three areas of minority language media policy and practice. International Journal of Applied Linguistics 21(1): 51-70.

Pietikäinen, S. \& H. Kelly-Holmes (2013). Multilingualism and the periphery. In: S. Pietikäinenn \& H. Kelly-Holmes (eds), Multilingualism and the Periphery. Oxford: OUP, 1-16.

Plas, P. (2007). Voicing folk for the academy: Interdiscursivity and collective identity in a North Dalmatian ethnography, 1899-1900. Journal of Pragmatics 39: 2244-2272.

Potkonjak, S. \& T. Škokić (2013). 'In the world of iron and steel'. On ethnography of work, unemployment and hope. Narodna Umjetnost 50(1): 74-96. 
Radić, P. (2010). Kopaonički govor: Etnogeografski i kulturološki pristup. Belgrade: Etnografski institut SANU.

Rešetar, M. (1907). Der štokavische Dialekt. Wien: Hölder.

Rihtman-Auguštin, D. (2001). Etnologija i etnomit. Zagreb: ABS95.

Schaller, H. W. (1975). Die Balkansprachen: Eine Einführung in die Balkanphilologie. Heidelberg: Carl Winter.

Stanonik, M. (2007). Slovenska narečna književnost. Maribor: Slavistično društvo.

Škaljić, A. (1966). Turcizmi u srpskohrvatskom jeziku. Sarajevo: Svjetlost.

Šotra, Z. (2002). Zona Zamfirova (Serbia).

Šotra, Z. (2005). Ivkova slava (Sebia).

Thurlow, C. (2010). Determined creativity: Language play in new media discourse. In: R. Jones (ed.), Discourse and Creativity. Harlow: Pearson, 169-190.

Timm, L. (2001). Ethnic identity and minority language survival in Brittany. In Language, Ethnicity and State, Vol. 1: Minority Languages in the European Union. C. C. O'Reilly (ed.), 104-127. New York NY: Palgrave Macmillan.

Toma, P. (1998). Govori Niša i okolnih sela [Srpski dijalektološki zbornik $\mathrm{XLV}$. Belgrade: SANU - Institut za srpski jezik.

Urban, G. (1984). Speech about speech in speech about action. Journal of American Folklore 97, 341-375.

Vojnov, D. (2004). Čitanje kulturnih fenomena: Srpski hip-hop. Gradina: Časopis za književnost, umetnost i kulturu 39(5).

Woolard, K. (2008). Language and identity choice in Catalonia: The interplay of contrasting ideologies of linguistic authority. In: K. Süselbeck, U. Mühlschlegel \& P. Masson (eds), Lengua, Nación e Identidad: La regulación del plurilingüismo en España y América Latina. Madrid \& Frankfurt: Iberoamericana \& Vervuert, 303-323.

Zlatanović, S. (2003). Svadba - priča o identitetu: Vranje i okolina. Belgrade: Ethnographic Institute of the Serbian Academy of Sciences and Arts.

Zlatanović, S. (2009). Književno delo Bore Stankovića i Vranje: Identitetske strategije, diskursi i prakse. Glasnik Etnografskog instituta SANU LVII(1): 51-69.

Received: 6 November 2017

Accepted for publication: 31 January 2018 
Тања Петровић

\title{
ЈЕЗИЧКА КРЕАТИВНОСТ: ПОГЛЕД СА ПЕРИФЕРИЈЕ СРПСКОГ ЈЕЗИЧКОГ ПРОСТОРА
}

\begin{abstract}
Сажетак
Чланак се бави језичким стратегијама аутора странице на Фејсбуку Кое има nо град, урбане хронике Лесковца, и текстова хип-хоп групе Southentik Crew из Власотница. У њему нудим поглед на креативност као стратешко мешање локалног дијалекта и других, лако препознатиљивих дискурса, и истражујем начине на које се у ова два примера употребе локалног дијалекта изазивају или потврђују језичка идеологија аутентичности и централистичка идеологија националног стандардног језика. Посебно ме занимају начини на које ова креативна употреба језика на периферији српског језичког и културног простора изазива и реогранизује фиксиране идеолошке односе између урбаног и руралног, локалног, националног и глобалног, те центра и периферије.
\end{abstract}

Кључне речи: дијалекат, креативност, југоисточна Србија, периферија, урбаност, језичка идеологија 